Article

\title{
An Agronomic Evaluation of New Safflower (Carthamus tinctorius L.) Germplasm for Seed and Oil Yields under Mediterranean Climate Conditions
}

\author{
Salvatore La Bella ${ }^{1}$, Teresa Tuttolomondo ${ }^{1, *}$, Luca Lazzeri ${ }^{2}$, Roberto Matteo ${ }^{2, *}$, Claudio Leto ${ }^{1,3}$ \\ and Mario Licata ${ }^{1,3}$ \\ 1 Department of Agricultural, Food and Forest Sciences, Università degli Studi di Palermo, \\ 90128 Palermo, Italy \\ 2 Consiglio per la Ricerca in Agricoltura e 1'Analisi dell'Economia Agraria, \\ Centro di Ricerca per la Cerealicoltura e le Colture industriali, 40128 Bologna, Italy \\ 3 Consorzio di Ricerca per lo Sviluppo di Sistemi Innovativi Agroambientali, Corissia, 90143 Palermo, Italy \\ * Correspondence: teresa.tuttolomondo@unipa.it (T.T.); roberto.matteo@crea.gov.it (R.M.); \\ Tel.: +39-091-12386-2227 (T.T.)
}

Received: 6 August 2019; Accepted: 16 August 2019; Published: 19 August 2019

\begin{abstract}
Interest in oilseed crops for agro-industrial research and development projects has increased in the Mediterranean area, in recent years. Safflower (Carthamus tinctorius L.) is of potential interest for agriculture mainly due to fatty acid content variability in the seed oil. The aim of this study was to assess the agronomic performance of 16 new safflower accessions together with safflower variety Montola 2000, used as a reference, in a semi-arid environment. Research was carried out in Sicily (Italy) from 2013-2014. Hierarchical cluster analysis carried out on the fatty acid composition of safflower accessions resulted in their division into four main groups. Linoleic, oleic and palmitic acids were the main fatty acids present in the accessions. Seed yield was $1.11 \mathrm{tha}^{-1}$ on average and seed oil content was found to be approximately $35.01 \%$ of dry matter on average. Positive and significant relationships between seed/oil yield and other tested traits were found. The carbon, hydrogen and nitrogen content as a percentage of dry matter varied greatly both for the above- and belowground plant parts on average. This study confirms the interest of safflower for both food and non-food applications, offering interesting prospects in semi-arid regions.
\end{abstract}

Keywords: Carthamus tinctorius; fatty acid composition; high linoleic safflower; high oleic safflower; semi-arid climate; Sicily

\section{Introduction}

Safflower (Carthamus tinctorius L.) is an annual oilseed crop belonging to the Asteraceae family. It is a xerophilous species native to Asia and the Mediterranean basin and grown in arid and semi-arid regions in the world [1,2]. It is a minor, underutilized oilseed crop, once grown for its dye called carthamin, extracted from dried, ground petals and used in fabric dyes [3-5]. Safflower is mostly used for cosmetic, food and medicinal purposes [6]; however, it may have potential as a fodder crop in Mediterranean cropping systems [7]. Nowadays, scientific interest in this species is mainly due to its high-quality vegetable oil for nutritional and industrial applications [8-10]. The nutritional value of safflower oil is, in fact, similar to that of olive oil [11] and, for this reason, the species has gained importance in recent years as a result of human consumption in arid and semi-arid regions. However, there is some evidence that safflower seeds oil might be suited to the production of biodiesel as the oil chemical characteristics would seem to be favourable when compared to those of other oils commonly used for biodiesel production [12]. As regards seed oil quality, safflower 
is amongst those crops which vary the widest in fatty acid composition [13-15]. The oil contains two main unsaturated fatty acids: Oleic and linoleic acids, which represent $90 \%$ of the total fatty acid content, while the remaining $10 \%$ corresponds to saturated fatty acids, such as palmitic and stearic acids [16-18]. In recent years, safflower has been widely investigated by the fields of genetic breeding and engineering through the manipulation and combination of the major genes that control fatty acid levels in the oil $[19,20]$. We are able, therefore, to distinguish two types of safflower varieties: A high oleic type, with an oleic acid content of up to $90.60 \%$, and a high linoleic type (linoleic acid content of up to $88.80 \%$ ) [21]. Traditional safflower oil, rich in polyunsaturated linoleic acid is valued for human health reasons as the high linoleic content leads to significant reductions in blood cholesterol levels $[15,16]$ although not suitable for prolonged frying due to low oxidative stability at high temperatures. On the contrary, oil which is rich in monounsaturated oleic acid shows high oxidative stability, which makes it suitable for food purposes and an alternative to olive oil in arid and semi-arid regions in the world $[2,11,22,23]$. Moreover, oleic acid is characterized by a high single point of unsaturation and this represents an attractive characteristic to industry due to the large range of potential chemical products. Oleic-rich safflower oil can be used in the production of varnishes, alcohols, paints, lubricants, cosmetics, detergents and bio-based plastics [16]. It is clear from literature that the genotype factor significantly affects fatty acid synthesis and proportions of oleic and linoleic acids during oil formation in the seed. However, at the same time, the ratio of oleic to linoleic acid in the seed oil is also dependent upon environmental variables, such as moisture and temperature during seed maturation [20]. As a consequence, genotype-environment interactions greatly influence the composition of safflower oil, as confirmed by various authors [21,24-26]. On the basis of this, the introduction of safflower into rainfed cropping systems in the Mediterranean area requires preliminary evaluation of the germplasm in order to verify the adaptation capacity of the species to specific climate conditions prior to its introduction into a cropping system. In Italy, safflower species were the subject of intense study in the 1990s as part of the Oilseed Project financed by the Italian Ministry of Agriculture and Forestry, which led to test trials in various areas of the country. The species was found to be highly adaptable, producing satisfactory yields compared to average yields produced in those areas of the world where the crop is commonly grown. Previous test trials generated valuable information on the yield and quality of the safflower oil. The high oleic and linoleic acid content made safflower a viable alternative to other oilseed crops for the marginal cropland in central-southern Italy; it was also considered for farm yield diversification in traditional cereal cropping systems. However, these findings did not result in any renewed interest or applications in successive years, which in turn led to the gradual disappearance of safflower from Italian research programs. Some authors [22] suggested that the main reason for the lack of safflower cultivation in central-southern Italy was the length of cropping cycle-approximately 240 days as a winter crop from November to July, or 145 days as a spring crop from February to July-together with low seed yield potential, approximately $1.00 \mathrm{tha}^{-1}$. Another reason given was the absence of financial support by the European Union, which was available, however, for the cultivation of major oilseed crops such as maize, rapeseed, soy and sunflower. In recent years in Italy, interest in oilseed crops in general for application in the non-food sector has increased, especially regarding industrial and research development projects [27-33]. In this context, safflower is a species of potential interest for agriculture and industry due to its high adaptability to soil and climate conditions and fatty acid variability in the seed oil. This paper reports the results, in the framework of the "BIT3G" Italian project, of two-year trials on 16 new safflower accessions, different in origin and never tested before in Italy. The aims of this study were: (i) To assess the agronomic performance of 16 new safflower accessions compared to the variety Montola 2000, used as a reference, in a semi-arid environment of Sicily (Italy); and (ii) to evaluate the fatty acid composition and qualitative characteristics of oils and biomasses. 


\section{Materials and Methods}

\subsection{Site Characterization and Main Cultivation Practices}

Tests on the agronomic assessment of 16 safflower accessions, see Figure S1, were performed during the cropping seasons 2012-2013 and 2013-2014 at the "Calogero Amato Vetrano" Agricultural

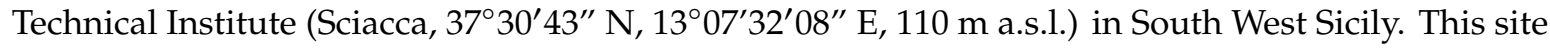
is characterized by a Mediterranean climate with mean annual rainfall of approximately $500 \mathrm{~mm}$, mainly distributed between October and April. With reference to time series 2000-2017, the average annual temperature is $18.60^{\circ} \mathrm{C}$. The soil, classified as Aric. Regosol by the United States Department of Agriculture (USDA), is sandy clay loam soil. Data on rainfall and air temperature were recorded by a weather station belonging to the Sicilian Agro-Meteorological Information Service [34] located $500 \mathrm{~m}$ from the experimental field. The station was synchronized with Greenwich Mean Time (GMT) in order to operate using synoptic forecast models. It was equipped with an MTX datalogger and various sensors for the measurement of air temperature, global solar radiation, leaf wetness, relative humidity, total rainfall and wind speed. Safflower seeds were obtained from the Regional Plant Introduction Station Washington State University (WRPIS) of the USDA. A total of 16 spiny accessions of safflower (code CTI), different in origin, were tested, as seen as in Table 1.

Table 1. List of safflower germplasm accessions in the study.

\begin{tabular}{lcc}
\hline Code & Spiny/Spineless & Origin \\
\hline CTI 1 & Spiny & Bangladesh \\
CTI 2 & Spiny & Bangladesh \\
CTI 3 & Spiny & Bangladesh \\
CTI 4 & Spiny & USA \\
CTI 5 & Spiny & Bangladesh \\
CTI 6 & Spiny & USA \\
CTI 7 & Spiny & USA \\
CTI 8 & Spiny & Canada \\
CTI 9 & Spiny & USA \\
CTI 10 & Spiny & Bangladesh \\
CTI 11 S 1 & Spiny & Italy \\
CTI 12 & Spiny & India \\
CTI 13 & Spiny & USA \\
CTI 14 & Spiny & Bangladesh \\
CTI 15 & Spiny & India \\
CTI 16 & Spiny & USA \\
CTI 17 & Spiny & Italy \\
\hline
\end{tabular}

The accessions were compared to safflower variety Montola 2000, used as a reference. The experimental design was a randomized complete block design with three replications and the test was conducted on plots each measuring $13.5 \mathrm{~m}^{2}$. The accessions were evaluated under dry (no irrigation) conditions. The previous crop was durum wheat. Soil was ploughed and harrowed beforehand. Safflower was sown on 7 January in 2013 and on 4 January in 2014. A density of 50 viable seeds $\mathrm{m}^{-2}$ was used and row spacing was $50 \mathrm{~cm}$. Before sowing, $80 \mathrm{~kg} \mathrm{ha}^{-1}$ of inorganic phosphorus was distributed. A total of $100 \mathrm{~kg} \mathrm{ha}^{-1}$ of nitrogen fertilizer was applied, $50 \mathrm{~kg} \mathrm{ha}^{-1}$ at sowing time, and $50 \mathrm{~kg} \mathrm{ha}^{-1}$ prior of stem elongation. Fluazifop-p-butyl 13:40\% at a rate of $1.00 \mathrm{~L} \mathrm{ha}^{-1}$ was applied at the emergence stage for graminaceous weed control, whilst dicotyledonous weeds were controlled mechanically. Insect control was carried out by dimethoate $98.00 \%$ at a rate of $1.50 \mathrm{~L} \mathrm{ha}^{-1}$ at the beginning of the flowering stage. Harvest was carried out (using a combine harvester equipped with a wheat-cutting bar at an interval of 10 days between 20 and 30 July both in 2013 and 2014) at seed ripening, when seed moisture content was below $8.00 \%$. 


\subsection{Agronomic and Chemical Parameters}

The main growth stages of the safflower accessions were determined according to an extended $\mathrm{BBCH}$-scale [35]. Seed yield was determined at the time of harvest, considering a harvest area of $7 \mathrm{~m}^{2}$. Plant height, number (no.) of branches per plant, number (no.) of capitula per plant and 1000-seed weight (TSW) were measured on a pool of 20 plants. For each accession, a total of three seed samples were analysed to determine the qualitative characteristics. After harvesting, seeds were cleaned, partially dried, ground to $10 \mathrm{~mm}$ and analyzed for their main components using the following procedures. The humidity content was determined by oven-drying the defatted seed meal (DSM) at $40{ }^{\circ} \mathrm{C}$ until constant weight and evaluating the difference in weight before and after treatment. The residual oil content was determined with an E-816 ECE extraction unit, by the continuous Twisselmann extraction method using hexane as solvent [36]. Carbon (C), hydrogen $(\mathrm{H})$ and nitrogen $(\mathrm{N})$ total contents were determined by dry combustion through an Elemental analyser LECO CHN TruSpec. The crude protein content was expressed as a percentage of dry matter (DM) and calculated from nitrogen using the conventional factor of $6.25[37,38]$. The fatty acid composition was determined by extracting the oil from ground seeds using hexane and trans-methylated in $2 \mathrm{NKOH}$ methanol solution [39]. Subsequently, fatty acid methyl ester composition was evaluated by gas chromatography equipped with a flame ionisation detector (Carlo Erba S.p.a., Milan, Italy. HRGC 5300 MEGA SERIES) and a capillary column Restek RT $\times 2330(30 \mathrm{~m} \times 0.25 \mathrm{~mm} \times 0.2 \mu \mathrm{m})$, following the internal normalisation method [40].

\subsection{Statistical Analyses}

Statistical analyses were performed using the software MINITAB Release 17 for Windows, and included analysis of variance, correlation and linear regression analysis. The difference between means was carried out using the Tukey test. Principal Component Analysis (PCA) and Hierarchical Cluster Analysis (HCA) using average linkage with squared Euclidean distance were also used in this study. PCA was used to reduce the high number of variables to low variables and to determine, in particular, how some variables, such as seed yield, oil yield and fatty acid composition of the oil, contribute to the total variation in the principal components.HCA was used to identify homogeneous groups of safflower accessions with similar fatty acid composition of the oil. These analyses were carried out with the software SPSS for Windows (version 17.0, Chicago, IL, USA). The values of C-H-N content of seeds and biomasses are shown as mean \pm standard deviation of calculations.

\section{Results}

\subsection{Analysis of Rainfall and Temperature Trends in the Test Site}

Rainfall and temperature trends during 2013 and 2014 are shown in Figure 1.

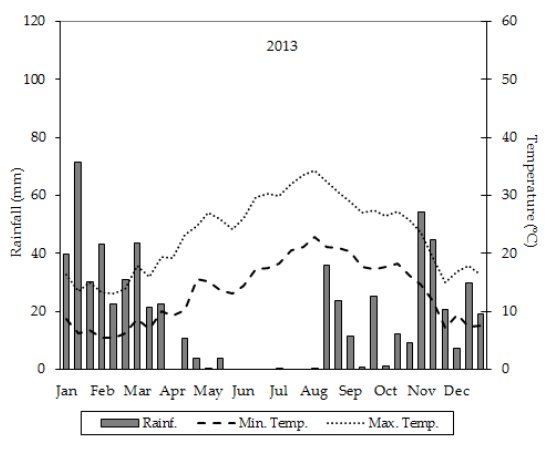

(a)

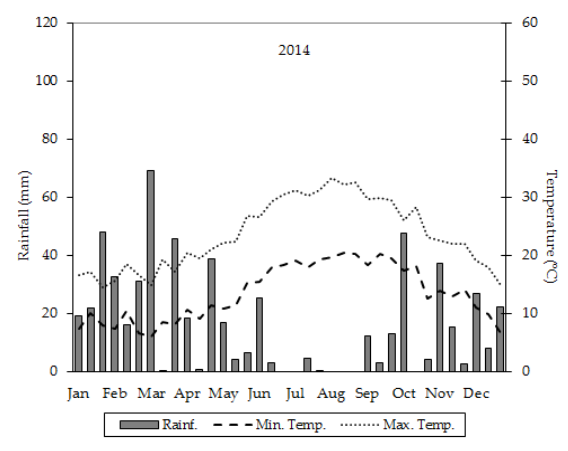

(b)

Figure 1. Rainfall and temperature trends during the test period. Graph (a) refers to 2013 while Graph (b) refers to 2014 . 
In the study area, the rainfall distribution was not uniform throughout the growth stages of the plants in both years, and rainy days were more concentrated in the winter season than in the spring and summer. This influenced the plant growth trend due to effects of rainfall frequency on safflower water needs. Total rainfall was higher in $2013(639 \mathrm{~mm})$ than $2014(596 \mathrm{~mm})$. The highest rainfall $(72 \mathrm{~mm})$ occurred in the second 10-day period of January 2013, subsequent to the sowing date. Despite this event, safflower plantlings and soil were not seriously damaged. Temperature trends were consistent with the ten-year average, with values never falling below zero. In both of the years, maximum and minimum temperatures decreased progressively from November to February and then increased up to June, when ripening occurred. The lowest minimum temperature $\left(2.31^{\circ} \mathrm{C}\right)$ was recorded in the third 10-day period of February 2013, when the plants were in the rosette growth stage and no damage or injuries were observed due to higher frost resistance of the plants in this stage. Mean minimum and maximum temperatures in the two growing seasons were similar and consistent with the ten-year average temperature. In summer, maximum temperatures ranged from 29 to $36^{\circ} \mathrm{C}$ and affected ripening and senescence stages. The highest maximum temperature $\left(39.31^{\circ} \mathrm{C}\right)$ was recorded in the third 10-day period of July 2013. Safflower plants did not show any heat damage when the maximum daily temperature rose to $30^{\circ} \mathrm{C}$ and rainfall was absent, confirming the high drought tolerance of this species.

\subsection{Growth Stages}

The main phenological stages observed in the study period are shown in Figure 2.

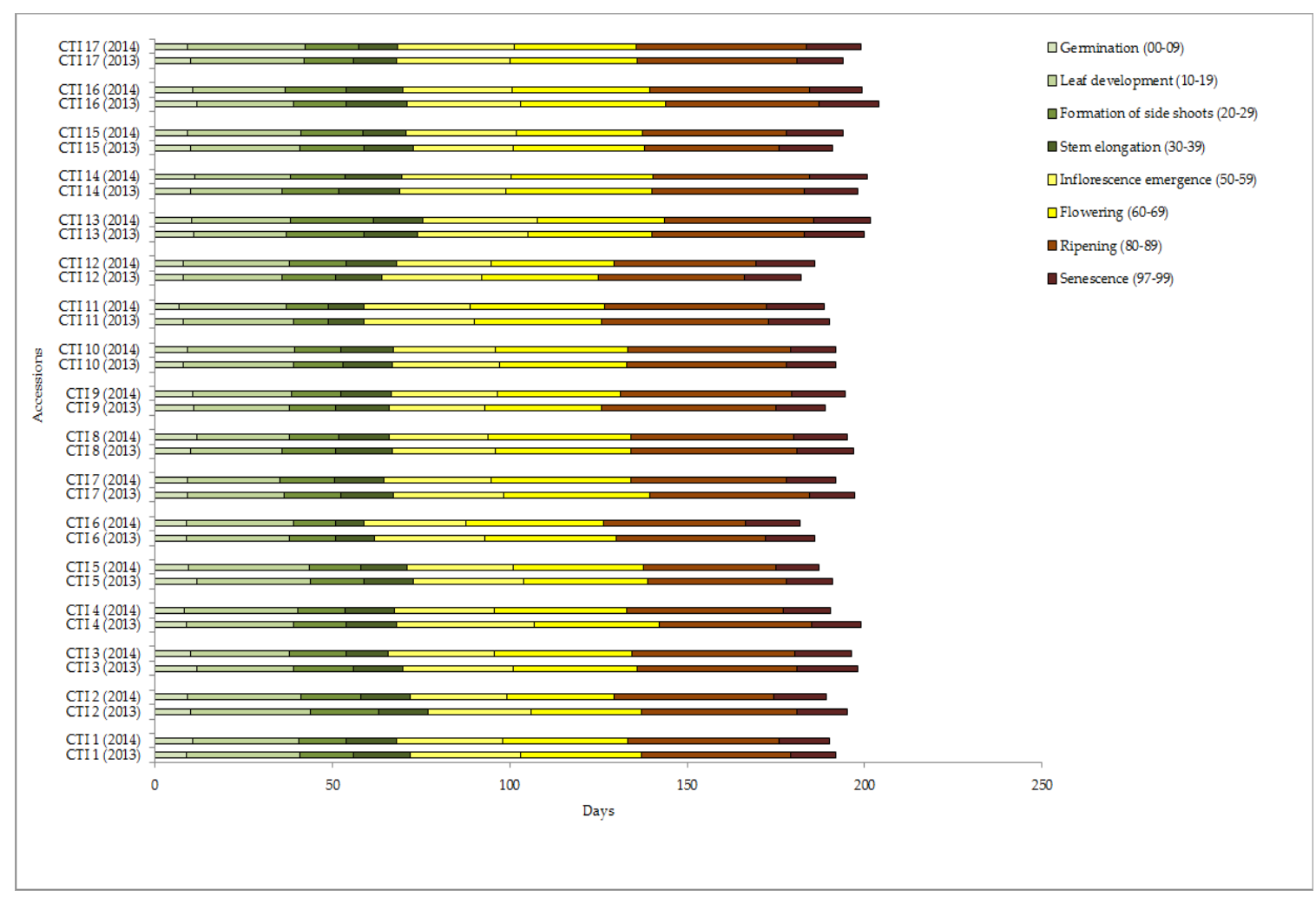

Figure 2. Phenological stages of safflower germplasm accessions in the study.

The phenological stage order was found to be similar for both years in all the safflower accessions. In general, the growth cycle length of the safflower germplasm was found to be close to the field average (193 days). CTI 6 and CTI 12 completed the growth cycle faster (184 days on average) than others. Germination stage occurred within 10 days and leaf development stage continued for the following 29 days on average during the test period. The formation of side shoots was recorded at 
the end of the winter season and it was not uniform for all the accessions. Stem elongation stage occurred between 8 and 17 days, when air temperature increased and extended internodes were visible. The length of the inflorescence emergence stage differed for all of the accessions. CTI 2 showed the earliest flowering compared to others. The flowering stage, as shown in Figure S2, was 36 days on average and the length of this growth stage influenced capitula development in the accessions. The shortest "days to ripening" was found in 4 accessions (127 days). Ripening stage lasted on average 44 days. Senescence stage, see in Figure S3, occurred when the plants became dry and the seeds were white and hard, see in Figure S4. Capitula browning occurred between 12 and 17 days on average. The growth cycle of the accessions was completed before the first 10-day period of July.

\subsection{Morphological and Yield Components Performance}

Results of analysis of variance revealed no significant differences between the two years for all the parameters tested. Concerning the accession factor, variations were highly significant for all parameters examined, as shown as in Table 2.

Table 2. Main morphological and yield traits of safflower germplasm accessions in the study.

\begin{tabular}{|c|c|c|c|c|c|c|c|}
\hline Factors & $\begin{array}{c}\text { Plant } \\
\text { Height }(\mathrm{cm})\end{array}$ & $\begin{array}{c}\text { No. } \\
\text { Branches }\end{array}$ & $\begin{array}{c}\text { No. } \\
\text { Capitula }\end{array}$ & TSW (g) & $\begin{array}{l}\text { Seed Yield } \\
\left(t \mathrm{ha}^{-1}\right)\end{array}$ & 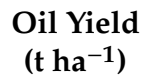 & $\begin{array}{c}\text { Oil Content } \\
(\%)\end{array}$ \\
\hline \multicolumn{8}{|l|}{ Year } \\
\hline 2013 & $122.65 \mathrm{~A}$ & $13.41 \mathrm{~A}$ & $13.47 \mathrm{~A}$ & $39.29 \mathrm{~A}$ & $1.13 \mathrm{~A}$ & $0.40 \mathrm{~A}$ & $35.65 \mathrm{~A}$ \\
\hline 2014 & $118.41 \mathrm{~A}$ & $12.86 \mathrm{~A}$ & $12.72 \mathrm{~A}$ & $39.02 \mathrm{~A}$ & $1.07 \mathrm{~A}$ & $0.37 \mathrm{~A}$ & $34.90 \mathrm{~A}$ \\
\hline \multicolumn{8}{|l|}{ Accession } \\
\hline CTI 1 & 105.83 DE & $13.83 \mathrm{AB}$ & $13.00 \mathrm{AB}$ & $38.33 \mathrm{~B}$ & 1.17 ABC & $0.42 \mathrm{ABC}$ & 35.66 BCD \\
\hline CTI 2 & $137.83 \mathrm{AB}$ & $13.51 \mathrm{AB}$ & $12.00 \mathrm{AB}$ & 38.05 B & $1.15 \mathrm{ABC}$ & $0.32 \mathrm{BC}$ & $27.50 \mathrm{EF}$ \\
\hline CTI 3 & 127.67 BC & $14.62 \mathrm{~A}$ & $14.33 \mathrm{~A}$ & $39.80 \mathrm{AB}$ & $1.33 \mathrm{AB}$ & $0.40 \mathrm{ABC}$ & $29.83 \mathrm{EF}$ \\
\hline CTI 4 & $120.50 \mathrm{BCDE}$ & $14.28 \mathrm{~A}$ & $14.48 \mathrm{~A}$ & $40.75 \mathrm{AB}$ & $1.37 \mathrm{AB}$ & $0.45 \mathrm{ABC}$ & $33.01 \mathrm{CDE}$ \\
\hline CTI 5 & 105.83 DE & $12.05 \mathrm{AB}$ & 10.65 B & 38.15 B & $0.92 \mathrm{BC}$ & $0.39 \mathrm{ABC}$ & 42.17 A \\
\hline CTI 6 & 109.83 CDE & $13.11 \mathrm{AB}$ & $12.58 \mathrm{AB}$ & $39.16 \mathrm{AB}$ & $1.23 \mathrm{ABC}$ & $0.51 \mathrm{AB}$ & $41.17 \mathrm{AB}$ \\
\hline CTI 7 & 103.83 E & 11.01 B & $11.45 \mathrm{AB}$ & 36.66 B & $0.95 \mathrm{BC}$ & $0.38 \mathrm{ABC}$ & $39.67 \mathrm{AB}$ \\
\hline CTI 8 & 128.67 BC & $14.50 \mathrm{~A}$ & $16.00 \mathrm{~A}$ & $41.10 \mathrm{AB}$ & $1.45 \mathrm{AB}$ & $0.40 \mathrm{ABC}$ & $27.33 \mathrm{EF}$ \\
\hline CTI 9 & 120.01 BCDE & $13.50 \mathrm{AB}$ & $13.63 \mathrm{AB}$ & $38.00 \mathrm{~B}$ & $1.25 \mathrm{ABC}$ & $0.50 \mathrm{AB}$ & $40.16 \mathrm{AB}$ \\
\hline CTI 10 & 101.16 E & 11.66 B & $11.50 \mathrm{AB}$ & $39.33 \mathrm{AB}$ & $0.91 \mathrm{BC}$ & $0.38 \mathrm{ABC}$ & $41.83 \mathrm{~A}$ \\
\hline CTI 11 & 113.67 CDE & $13.31 \mathrm{AB}$ & $12.66 \mathrm{AB}$ & $39.65 \mathrm{AB}$ & $1.20 \mathrm{ABC}$ & $0.46 \mathrm{ABC}$ & 38.17 ABC \\
\hline CTI 12 & 149.17 A & $12.66 \mathrm{AB}$ & $12.73 \mathrm{AB}$ & $39.83 \mathrm{AB}$ & $1.10 \mathrm{ABC}$ & $0.29 \mathrm{C}$ & $26.50 \mathrm{~F}$ \\
\hline CTI 13 & 118.83 BCDE & $13.50 \mathrm{AB}$ & $13.75 \mathrm{AB}$ & 38.33 B & $0.83 \mathrm{BC}$ & $0.31 \mathrm{BC}$ & $37.83 \mathrm{ABC}$ \\
\hline CTI 14 & 124.01 BCD & 11.93 B & $11.83 \mathrm{AB}$ & $37.41 \mathrm{~B}$ & $0.83 \mathrm{BC}$ & $0.23 \mathrm{C}$ & $28.01 \mathrm{EF}$ \\
\hline CTI 15 & 127.17 BC & $14.25 \mathrm{~A}$ & $14.50 \mathrm{~A}$ & 38.13 B & $1.25 \mathrm{ABC}$ & $0.54 \mathrm{~A}$ & $43.16 \mathrm{~A}$ \\
\hline CTI 16 & 117.83 BCDE & $11.00 \mathrm{~B}$ & $11.00 \mathrm{~B}$ & $40.78 \mathrm{AB}$ & $0.70 \mathrm{C}$ & $0.22 \mathrm{C}$ & 31.83 DEF \\
\hline CTI 17 & 137.67 AB & $14.65 \mathrm{~A}$ & $16.00 \mathrm{~A}$ & $43.25 \mathrm{~A}$ & $1.64 \mathrm{~A}$ & $0.59 \mathrm{~A}$ & 35.83 BCD \\
\hline
\end{tabular}

The values followed by the same letter are not significantly different for $p \leq 0.01$ according to the Test of Tukey.

In particular, safflower accessions were significantly different as regards plant height, ranging from 101.16 (CTI 10) to $149.17 \mathrm{~cm}$ (CTI 12), with an average value of $121.07 \mathrm{~cm}$. Plant height is a morphological parameter under genetic control; however, its manifestation could depend on environmental factors, such as altitude, air temperature, solar radiation and percentage of moisture in the air and in the soil. It is reasonable to suppose that the varying origins of the safflower accessions affected the value of this trait. Accessions showed significant differences regarding the number of branches per plant. The maximum and minimum values of the number of branches per plant were 14.65 (CTI 17) and 11.01 (CTI 7), respectively, with an average value of 13 . Significant differences among the accessions were recorded for number of capitula per plant. CTI 17 and CTI 8 showed the highest number of capitula per plant (16) while CTI 16 showed the lowest on average (11). The average value of number of capitula per plant was 13.06. The maximum value for TSW (43.25 g) was recorded in CTI 17. Accessions CTI 7 and 14 produced the minimum value ( $37.03 \mathrm{~g}$, on average) for TSW. The average value of TSW was 
39.21 g. In Particular, CTI 17 yielded the highest values for number of capitula per plant and TSW. As regards yield parameters, significant differences were found for seed yield, oil content and oil yield. The highest value for seed yield $\left(1.64 \mathrm{tha}^{-1}\right)$ was recorded for CTI 17 while the lowest $\left(0.70 \mathrm{tha} \mathrm{h}^{-1}\right)$ for CTI 16; average seed yield was $1.11 \mathrm{t} \mathrm{ha}^{-1}$. Seed oil content was around $35.02 \%$ of dry matter on average, ranging from $26.51 \%$ (CTI 12) to $43.22 \%$ (CTI 5). Oil yield was $0.39 \mathrm{t} \mathrm{ha}^{-1}$ on average. CTI 17 gave the highest seed oil yield $\left(0.59 \mathrm{t} \mathrm{ha}^{-1}\right)$ while CTI 16 the lowest $\left(0.22 \mathrm{tha}^{-1}\right)$. The ability of accessions CTI 17 and CTI $15\left(0.54 \mathrm{t} \mathrm{ha}^{-1}\right)$ to produce maximum oil yields was due to higher significant values of seed yield and oil content percentage.

\subsection{Fatty Acid Composition and Qualitative Characteristics of Oils and Biomasses}

Hierarchical cluster analysis carried out on fatty acid composition of safflower accessions in the study resulted in their division into four main groups, see in Table 3.

Table 3. Fatty acid composition of the four groups of safflower accessions obtained by cluster analysis. Average \pm standard deviation values are shown.

\begin{tabular}{ccccc}
\hline Fatty Acids & Group 1 $(\mathbf{n}=\mathbf{4})$ & Group 2 $(\mathbf{n}=\mathbf{4})$ & Group 3 $(\mathbf{n}=\mathbf{8})$ & Group 4 (n = 1) \\
\hline Arachidic acid & $0.15 \pm 0.17$ & $0.29 \pm 0.03$ & $0.44 \pm 0.04$ & $0.40 \pm 0.02$ \\
Behenic acid & $0.13 \pm 0.15$ & $0.15 \pm 0.11$ & $0.32 \pm 0.04$ & $0.30 \pm 0.01$ \\
Gadoleic acid & $0.05 \pm 0.10$ & $0.10 \pm 0.10$ & $0.26 \pm 0.06$ & $0.20 \pm 0.00$ \\
Linoleic acid & $58.79 \pm 6.06$ & $73.88 \pm 3.90$ & $19.02 \pm 3.77$ & $32.10 \pm 0.02$ \\
Oleic acid & $32.41 \pm 5.83$ & $17.13 \pm 3.70$ & $72.00 \pm 3.80$ & $58.80 \pm 0.01$ \\
Palmitic acid & $5.95 \pm 0.26$ & $5.96 \pm 0.21$ & $5.26 \pm 0.15$ & $5.40 \pm 0.03$ \\
Stearic acid & $2.26 \pm 0.14$ & $2.32 \pm 0.12$ & $2.27 \pm 0.24$ & $2.30 \pm 0.01$ \\
Others & $0.26 \pm 0.08$ & $0.16 \pm 0.10$ & $0.42 \pm 0.20$ & $0.50 \pm 0.03$
\end{tabular}

Group 1: CTI 4, CTI 3, CTI 14, CTI 7; Group 2: CTI 2, CTI 12, CTI 8, CTI 16; Group 3: CTI 5, CTI 9, CTI 15, CTI 17, CTI 1, CTI 6, CTI 11, CTI 10; Group 4: CTI 13.

This division was based on the different quantitative relationships between the seed oil fatty acids, such as arachidic, behenic, gadoleic, linoleic, oleic, palmitic, stearic and other acids. The first cluster (Group 1) consisted of 4 accessions, the second (Group 2) of 4, the third (Group 3) of 8 and the fourth (Group 4) of only 1 accession. Group 1 contained accessions with a medium content of linoleic acid $(58.80 \pm 6.06 \%)$ and oleic acid $(32.41 \pm 5.83 \%)$. Accessions belonging to Group 2 were characterised by a higher linoleic acid content $(73.88 \pm 3.90 \%)$ and a lower content of oleic acid $(17.13 \pm 3.70 \%)$. The third Group contained the largest number of accessions (8), all of which showed the highest percentage content of oleic acid $(72.00 \pm 3.80 \%)$ and the lowest content of linoleic acid $(19.02 \pm 3.77 \%)$. The single accession belonging to Group 4 (CTI 13) was characterised by a medium percentage content of linoleic acid $(32.10 \pm 0.02 \%)$ and oleic acid $(58.80 \pm 0.01 \%)$. In general, most of safflower accessions showed a high percentage content of oleic acid. The evaluation of C-H-N content as a percentage of dry matter obtained from DSM showed that the highest fraction was found for carbon and the lowest for nitrogen in all the accessions, see in Table 4. 
Table 4. C-H-N content and protein as percentage of dry matter in seeds of safflower germplasm accessions in the study. Average \pm standard deviation values are shown.

\begin{tabular}{ccccc}
\hline Accession & C (\% DM) & H (\% DM) & N (\% DM) & Protein (\% DM) \\
\hline CTI 1 & $61.17 \pm 0.83$ & $8.51 \pm 0.44$ & $2.89 \pm 0.25$ & $16.40 \pm 1.84$ \\
CTI 2 & $59.45 \pm 0.15$ & $7.93 \pm 0.24$ & $2.78 \pm 0.27$ & $18.61 \pm 1.58$ \\
CTI 3 & $59.55 \pm 0.14$ & $8.22 \pm 0.30$ & $2.55 \pm 0.04$ & $15.72 \pm 0.08$ \\
CTI 4 & $60.94 \pm 0.46$ & $8.44 \pm 0.28$ & $2.13 \pm 0.12$ & $13.71 \pm 0.92$ \\
CTI 5 & $64.65 \pm 0.26$ & $8.94 \pm 0.52$ & $3.45 \pm 0.22$ & $21.20 \pm 1.52$ \\
CTI 6 & $61.01 \pm 0.01$ & $8.50 \pm 0.33$ & $2.66 \pm 0.15$ & $16.31 \pm 0.99$ \\
CTI 7 & $62.43 \pm 0.16$ & $8.61 \pm 0.30$ & $2.89 \pm 0.11$ & $19.11 \pm 0.77$ \\
\hline CTI 8 & $60.90 \pm 0.41$ & $7.76 \pm 0.29$ & $2.36 \pm 0.24$ & $14.71 \pm 0.02$ \\
CTI 9 & $61.94 \pm 0.24$ & $8.81 \pm 0.35$ & $2.91 \pm 0.15$ & $17.41 \pm 1.44$ \\
CTI 10 & $63.48 \pm 0.25$ & $8.99 \pm 0.29$ & $3.04 \pm 0.10$ & $19.72 \pm 0.92$ \\
CTI 11 & $61.90 \pm 0.09$ & $8.71 \pm 0.36$ & $1.99 \pm 0.05$ & $12.31 \pm 0.38$ \\
CTI 12 & $58.65 \pm 0.73$ & $8.01 \pm 0.24$ & $2.53 \pm 0.10$ & $16.31 \pm 0.01$ \\
CTI 13 & $61.28 \pm 0.01$ & $8.20 \pm 0.18$ & $2.82 \pm 0.27$ & $18.50 \pm 1.91$ \\
CTI 14 & $61.13 \pm 0.12$ & $8.09 \pm 0.17$ & $2.69 \pm 0.06$ & $17.31 \pm 0.39$ \\
CTI 15 & $62.27 \pm 0.05$ & $8.92 \pm 0.37$ & $3.65 \pm 0.10$ & $22.11 \pm 0.36$ \\
CTI 16 & $60.80 \pm 0.40$ & $8.20 \pm 0.23$ & $2.39 \pm 0.11$ & $15.91 \pm 0.07$ \\
CTI 17 & $61.23 \pm 0.20$ & $8.46 \pm 0.28$ & $2.44 \pm 0.03$ & $15.13 \pm 0.19$ \\
\hline
\end{tabular}

Considering seed protein content, CTI 15 had the highest value $(22.11 \%)$, showing an interesting potential both for oil production $\left(0.55 \mathrm{t} \mathrm{ha}^{-1}\right)$ and feed/functional food applications. The lowest value $(12.31 \%)$ was, instead, found in CTI 11. The average seed protein content of all the accessions was $17.11 \%$ of dry matter.

Regarding biomass, above- and belowground parts showed the highest carbon content and the lowest nitrogen content as a percentage of dry matter, see in Table 5.

Table 5. C-H-N content as a percentage of dry matter in aboveground and belowground biomass of safflower germplasm accessions in the study. Average \pm standard deviation values are shown.

\begin{tabular}{|c|c|c|c|c|c|c|}
\hline \multirow{2}{*}{ Accession } & \multicolumn{2}{|c|}{ C (\% DM) } & \multicolumn{2}{|c|}{ H (\% DM) } & \multicolumn{2}{|c|}{ N (\% DM) } \\
\hline & $\mathrm{AG}^{1}$ & BG $^{2}$ & AG & BG & AG & BG \\
\hline CTI 1 & $47.33 \pm 1.20$ & $48.43 \pm 0.36$ & $6.88 \pm 0.62$ & $6.21 \pm 0.17$ & $1.01 \pm 0.12$ & $0.60 \pm 0.16$ \\
\hline CTI 2 & $47.73 \pm 0.32$ & $48.10 \pm 0.71$ & $6.66 \pm 0.01$ & $6.17 \pm 0.07$ & $0.91 \pm 0.01$ & $0.49 \pm 0.03$ \\
\hline CTI 3 & $49.11 \pm 0.86$ & $47.44 \pm 0.32$ & $6.83 \pm 0.24$ & $6.15 \pm 0.01$ & $0.89 \pm 0.15$ & $0.59 \pm 0.11$ \\
\hline CTI 4 & $48.43 \pm 0.31$ & $46.40 \pm 0.11$ & $6.72 \pm 0.03$ & $6.09 \pm 0.01$ & $0.83 \pm 0.02$ & $0.55 \pm 0.01$ \\
\hline CTI 5 & $48.17 \pm 0.01$ & $45.68 \pm 0.75$ & $6.75 \pm 0.02$ & $5.82 \pm 0.21$ & $1.23 \pm 0.10$ & $0.81 \pm 0.01$ \\
\hline CTI 6 & $47.55 \pm 0.32$ & $48.84 \pm 0.61$ & $6.55 \pm 0.17$ & $6.35 \pm 0.06$ & $0.86 \pm 0.05$ & $0.64 \pm 0.04$ \\
\hline CTI 7 & $47.97 \pm 0.39$ & $44.46 \pm 0.69$ & $6.68 \pm 0.03$ & $5.95 \pm 0.28$ & $0.91 \pm 0.05$ & $0.44 \pm 0.08$ \\
\hline CTI 8 & $48.13 \pm 0.69$ & $45.89 \pm 0.51$ & $6.59 \pm 0.09$ & $6.01 \pm 0.07$ & $0.65 \pm 0.04$ & $0.36 \pm 0.01$ \\
\hline CTI 9 & $48.08 \pm 0.07$ & $48.81 \pm 0.96$ & $6.67 \pm 0.03$ & $6.35 \pm 0.06$ & $1.02 \pm 0.17$ & $0.61 \pm 0.03$ \\
\hline CTI 10 & $48.28 \pm 0.36$ & $47.46 \pm 0.39$ & $6.52 \pm 0.15$ & $6.12 \pm 0.07$ & $0.94 \pm 0.04$ & $0.66 \pm 0.08$ \\
\hline CTI 11 & $48.27 \pm 0.94$ & $42.74 \pm 0.59$ & $6.57 \pm 0.11$ & $5.56 \pm 0.09$ & $0.56 \pm 0.02$ & $0.43 \pm 0.07$ \\
\hline CTI 12 & $47.57 \pm 0.37$ & $47.29 \pm 0.51$ & $6.51 \pm 0.05$ & $6.27 \pm 0.02$ & $0.97 \pm 0.01$ & $0.59 \pm 0.01$ \\
\hline CTI 13 & $48.40 \pm 0.37$ & $48.27 \pm 0.73$ & $6.29 \pm 0.20$ & $6.12 \pm 0.10$ & $1.02 \pm 0.01$ & $0.68 \pm 0.02$ \\
\hline CTI 14 & $47.85 \pm 0.16$ & $46.75 \pm 0.81$ & $6.39 \pm 0.08$ & $6.08 \pm 0.10$ & $0.96 \pm 0.18$ & $0.59 \pm 0.01$ \\
\hline CTI 15 & $48.46 \pm 0.75$ & $44.54 \pm 0.75$ & $6.70 \pm 0.10$ & $5.71 \pm 0.08$ & $1.12 \pm 0.01$ & $0.77 \pm 0.13$ \\
\hline CTI 16 & $48.20 \pm 0.69$ & $47.08 \pm 0.07$ & $6.53 \pm 0.09$ & $6.18 \pm 0.01$ & $0.80 \pm 0.03$ & $0.36 \pm 0.01$ \\
\hline CTI 17 & $48.67 \pm 0.85$ & $48.22 \pm 0.44$ & $6.45 \pm 0.10$ & $6.25 \pm 0.04$ & $0.87 \pm 0.01$ & $0.47 \pm 0.06$ \\
\hline
\end{tabular}

${ }^{1}$ Aboveground biomass; ${ }^{2}$ belowground biomass. 


\subsection{Correlation and Linear Regression Analysis}

The relationships between morphological and yield parameters of the accessions were identified based on the findings of correlation and linear regression analysis carried out on all agronomic traits in the study.

Correlation analysis, as seen as in Table 6 showed how seed yield was positively and significantly correlated with number of branches per plant $(r=0.90)$, number of capitula per plant $(r=0.96)$, TSW $(r=0.79)$ and oil yield $(r=0.73)$.

Table 6. Pearson correlation coefficients for morphological and yield traits of safflower germplasm accessions.

\begin{tabular}{|c|c|c|c|c|c|c|}
\hline Traits & $\begin{array}{c}\text { No. } \\
\text { Branches }\end{array}$ & $\begin{array}{c}\text { No. } \\
\text { Capitula }\end{array}$ & TSW (g) & $\begin{array}{l}\text { Seed Yield } \\
\left(\mathrm{t} \mathrm{ha}^{-1}\right)\end{array}$ & $\begin{array}{l}\text { Oil Content } \\
(\%)\end{array}$ & $\begin{array}{l}\text { Oil Yield } \\
\left(\mathrm{t} \mathrm{ha}^{-1}\right)\end{array}$ \\
\hline No. branches (n) & 1.00 & & & & & \\
\hline No. capitula (n) & $0.89 * *$ & 1.00 & & & & \\
\hline TSW $(\mathrm{g})$ & $0.57 * *$ & $0.79 * *$ & 1.00 & & & \\
\hline Seed yield $\left(\mathrm{t} \mathrm{ha}{ }^{-1}\right)$ & $0.90^{* *}$ & $0.96^{* *}$ & $0.79 * *$ & 1.00 & & \\
\hline Oil content (\%) & -0.16 & -0.21 & -0.21 & -0.13 & 1.00 & \\
\hline Oil yield $\left(\mathrm{t} \mathrm{ha}^{-1}\right)$ & $0.67^{* *}$ & $0.67^{* *}$ & $0.54^{* *}$ & $0.73^{* *}$ & $0.52 * *$ & 1.00 \\
\hline
\end{tabular}

** Means are highly significant at 0.01 level of probability.

In addition, the oil yield was positively and significantly correlated with number of branches per plant $(r=0.67)$, number of capitula per plant $(r=0.67)$, TSW $(r=0.54)$ and oil content percentage $(r=0.52)$. Linear regression analysis, see in Table 7 , highlighted that a positive increase in morphological and yield parameters determined a positive and significant increase in seed and oil yields.

Table 7. Regression equation and coefficient of determination $\left(\mathrm{R}^{2}\right)$ for response of dependence variables $(\mathrm{Y})$ to independence variables $(\mathrm{X})$ of 17 safflower germplasm accessions.

\begin{tabular}{cccc}
\hline Independence Variable (X) & Dependence Variable (Y) & Regression Equation & $\mathbf{R}^{\mathbf{2}} \mathbf{( \% )}$ \\
\hline \multirow{2}{*}{ Plant height } & Seed yield & $\mathrm{Y}=0.82+0.09 \mathrm{X}$ & $17.61^{* *}$ \\
& Oil yield & $\mathrm{Y}=4.00-0.00 \mathrm{X}$ & 0.01 \\
\hline \multirow{2}{*}{ Number of branches } & Seed yield & $\mathrm{Y}=-6.90+1.39 \mathrm{X}$ & $81.90^{* *}$ \\
& Oil yield & $\mathrm{Y}=-1.81+0.45 \mathrm{X}$ & $45.10^{* *}$ \\
\hline \multirow{2}{*}{ Number of capitula } & Seed yield & $\mathrm{Y}=-4.87+1.24 \mathrm{X}$ & $91.91^{* *}$ \\
& Oil yield & $\mathrm{Y}=-0.87+0.38 \mathrm{X}$ & $44.92^{* *}$ \\
\hline \multirow{2}{*}{ TSW } & Seed yield & $\mathrm{Y}=-41.77+1.35 \mathrm{X}$ & $62.82^{* *}$ \\
& Oil yield & $\mathrm{Y}=-11.74+0.40 \mathrm{X}$ & $29.20^{* *}$ \\
\hline \multirow{2}{*}{ Oil content } & Seed yield & $\mathrm{Y}=13.33-0.06 \mathrm{X}$ & 1.81 \\
Oil yield & Oil yield & $\mathrm{Y}=0.23+0.10 \mathrm{X}$ & $27.32^{* *}$ \\
\hline Seed yield & Seed yield & $\mathrm{Y}=0.45+0.31 \mathrm{X}$ & $53.81^{* *}$ \\
\hline
\end{tabular}

** Means are highly significant at 0.01 level of probability.

Seed yield increased linearly with plant height $\left(R^{2}=17.61 \%\right)$, number of branches per plant $\left(\mathrm{R}^{2}=81.90 \%\right)$, number of capitula per plant $\left(\mathrm{R}^{2}=91.91 \%\right)$, $\mathrm{TSW}\left(\mathrm{R}^{2}=62.82 \%\right)$ and oil yield $\left(\mathrm{R}^{2}=53.82 \%\right)$. No significant linear regression was found between oil content percentage and seed yield. Concerning oil yield, as a dependence variable, it increased linearly with number of branches $\left(R^{2}=45.10 \%\right)$, number of capitula per plant $\left(R^{2}=44.92 \%\right)$, TSW $\left(R^{2}=29.20 \%\right)$, oil content $\left(R^{2}=27.32 \%\right)$ and seed yield $\left(R^{2}=53.81 \%\right)$. However, no significant linear regression was found between plant height and oil yield. 


\subsection{Principal Component Analysis}

PCA was applied to both morphological and yield traits, plant phenological stages and fatty acid composition of safflower germplasm accessions. Six principal components were identified, which explained $90.49 \%$ of the total variation, all with eigenvalues greater than one, see in Table 8 .

Table 8. Eigenvectors and eigenvalues generated by PCA carried out on morphological and yield traits, plant phenological stages and fatty acid composition of safflower germplasm accessions.

\begin{tabular}{|c|c|c|c|c|c|c|}
\hline \multirow{2}{*}{ Variable } & \multicolumn{6}{|c|}{ Eigenvectors } \\
\hline & PC1 & PC2 & PC3 & PC4 & PC5 & PC6 \\
\hline Plant height (cm) & 0.41 & 0.49 & 0.63 & -0.05 & 0.05 & 0.33 \\
\hline No. branches & 0.86 & -0.07 & 0.28 & 0.23 & -0.16 & 0.06 \\
\hline No. capitula & 0.94 & 0.15 & 0.09 & 0.18 & 0.60 & 0.11 \\
\hline $\mathrm{TSW}(\mathrm{g})$ & 0.89 & 0.17 & -0.12 & -0.01 & 0.22 & 0.03 \\
\hline Seed yield $\left(t \mathrm{ha}^{-1}\right)$ & 0.98 & -0.02 & 0.08 & 0.10 & -0.01 & 0.03 \\
\hline Oil yield $\left(\mathrm{t} \mathrm{ha}^{-1}\right)$ & 0.80 & -0.54 & -0.11 & 0.23 & -0.18 & 0.09 \\
\hline Oil content $(\%)$ & -0.10 & -0.80 & -0.43 & -0.15 & -0.26 & 0.03 \\
\hline Days to germination (n) & -0.20 & 0.75 & -0.11 & 0.01 & 0.88 & -0.23 \\
\hline Days to leaf development (n) & 0.29 & -0.22 & -0.13 & -0.49 & -0.35 & 0.65 \\
\hline Days to formation of side shoots (n) & -0.41 & 0.10 & 0.88 & -0.07 & -0.14 & 0.24 \\
\hline Days to stem elongation (n) & -0.49 & 0.41 & -0.10 & 0.18 & 0.59 & 0.20 \\
\hline Days to inflorescence emergence (n) & 0.08 & -0.70 & 0.07 & 0.10 & 0.45 & -0.14 \\
\hline Days to flowering (n) & -0.07 & 0.38 & -0.15 & -0.46 & 0.09 & 0.94 \\
\hline Days to ripening (n) & 0.32 & 0.09 & -0.15 & 0.83 & 0.20 & 0.05 \\
\hline Days to senescence (n) & 0.10 & 0.05 & 0.88 & 0.28 & -0.02 & -0.17 \\
\hline Oleic acid (\%) & 0.13 & 0.95 & -0.19 & -0.10 & -0.08 & 0.08 \\
\hline Linoleic acid (\%) & -0.13 & 0.95 & 0.20 & 0.09 & 0.07 & -0.09 \\
\hline Palmitic acid (\%) & 0.25 & 0.82 & -0.25 & 0.13 & 0.11 & -0.06 \\
\hline \multirow[t]{2}{*}{ Stearic acid (\%) } & 0.14 & 0.14 & 0.37 & 0.83 & -0.13 & -0.09 \\
\hline & \multicolumn{6}{|c|}{ Eigenvalues } \\
\hline Total eigenvalue & 5.27 & 5.18 & 2.51 & 2.04 & 1.14 & 1.05 \\
\hline Percent of total variance explained (\%) & 27.73 & 27.30 & 13.20 & 10.74 & 5.98 & 5.52 \\
\hline Cumulative percent of total variance explained (\%) & 27.73 & 55.03 & 68.24 & 78.98 & 84.96 & 90.49 \\
\hline
\end{tabular}

The first principal component (PC1) explained $27.73 \%$ of the total variation, showing the highest contributions from the proportions of morphological and yields variables. The second principal component (PC2) contributed to $27.30 \%$ of the total variation and received higher contributions from oil content and fatty acid composition. Among the eigenvectors of PC2, the proportions of oil content, oleic, linoleic and palmitic acid had the highest values. The third (PC3), fourth (PC4), fifth (PC5) and sixth (PC6) principal components explained $13.20 \%, 10.74 \%, 5.98 \%$ and $5.52 \%$ of the total variation, respectively. Plant phenological stage variable was more influential in these latter principal components. In fact, PC3 was characterised by the highest values for days to formation of side shoots and days to senescence. Among the eigenvectors of PC4, days to ripening and stearic acid percentage had the highest values. PC5 received higher contributions from days to germination, whilst PC6 showed highest contributions from days to flowering. PCA identified number of capitula, seed yield, oleic acid, linoleic acid and days to flowering as the most important variables responsible for variation in the 17 safflower germplasm accessions. It is important to note that the best safflower accessions could be selected based on these principal components.

\section{Discussion}

In agricultural experiments, the evaluation of any new plant germplasm in a cultivation area usually aims to verify the adaptation capacity of the accessions/varieties to specific climate conditions and to determine their potential yield and performance in the area. Based on these results, farmers are 
able to plan the introduction of new germplasm into cropping systems in order to improve and diversify the variety selection and increase their income. In this research, 16 new safflower accessions of different origin were tested for the first time in an area where cereal crops, such as durum wheat and barley, are traditionally cultivated. All the accessions showed high capacity to adapt to the semi-arid climate conditions in the study area and few differences were recorded for each phenological stage during the two years. High tolerance to the lowest minimum temperatures was observed in all the accessions at rosette growth stage, whilst an excellent capacity of the species to exploit the winter rainfall and resistance to water stress conditions was detected in the spring and summer seasons. However, significant differences in terms of morphological and yield parameters were found between accessions during the test period. These differences can be explained considering both genetic and environmental factors. Various authors [41] have found that genetic variation occurring in safflower germplasm grown in rainfed, cold, drylands greatly affects seed yield. Others [42] have said that environmental factors, such as solar radiation, soil moisture and water, air temperature, and soil nutrient content can significantly influence yield performances of safflower varieties, therefore, the same variety is able to produce different yields under different climate conditions. In our study, all safflower accessions were compared under the same climate conditions and cultivation practices, therefore, the main seed and oil yield differences were due to genotype response to environmental conditions. Literature highlights the fact that an evaluation of morphological and yield parameters and the way in which they are related is fundamental in order to fully understand how the direct components of the yield are related to the various morphological parameters of the species and vice versa. Plant height, number of branches per plant, number of capitula, thousand seed weight and oil content percentage are considered the most important morphological and yield parameters concerning seed yield because of the direct correlation between these characteristics and seed yield [13]. However, there seems to be no agreement in previous studies on which are the most important yield components and how each morphological parameter can affect the seed and oil yields of safflower. In a study of 10 safflower populations, it was found that the number of capitula per plant was the most important yield parameter and it was positively correlated with seed yield [43]. 100 exotic and indigenous safflower pure lines were compared in North West of Iran and it was observed that only number of seeds per capitulum and plant height had high correlations with seed yield [44]. In Turkey, a study reported the relationships between different characteristics of safflower and indicated that seed yield was highly correlated with oil yield [13]. In Iran, authors assessed the agronomic performances of 100 safflower genotypes and reported that the most important yield components were significantly inter-correlated, noting that the number of capitula per plant was not correlated with number of seeds per capitulum [5]. On the contrary, in Italy, it was found that the number of capitula per plant was positively and significantly correlated with number of seeds per capitulum [45]. In Egypt, when considering 25 safflower genotypes, positive and significant relationships were observed between oil yield and all morphological and yield parameters in the study [2]. In our study, we found highly significant correlation values between seed yield and other yield components. This highlights the fact that seed yield can be increased only by maximizing the other yield components, for example through integrated crop management practices. However, evaluation of the adaptation of accession/variety germplasm to specific environmental conditions must come first. Concerning seed yield, literature reports values ranging from 1.00 to $5.00 \mathrm{tha}^{-1}$ on average, mainly due to cultivation practices and environmental conditions $[2,5,13,46,47]$. No recent information is available on safflower seed yield values in Italy due to the progressive disappearance of the species from Italian cropping systems. In Southern Italy in particular, a study reported seed test plot results ranging from 0.50 to $2.50 \mathrm{tha}^{-1}$ on average, to be used as a reference [4]. Comparing these yields with the results of our study, it was shown that seed yield was on average lower than those found in other cropping areas. This emphasises the fact that the climate conditions greatly affect seed yield performances of safflower, despite the high rusticity and adaptability of the species to various environments. Moreover, another reason for these differences is, without doubt, the effect of agronomic factors, such as sowing density, fertilization and irrigation, on yield. Unquestionably, oil content 
significantly affects whether the species can be introduced into new cropping areas or not; therefore, this trait must be considered as one of the main yield components [13,48]. Oil content of safflower germplasms can vary significantly according to the genetic characteristics of the plants, climate and soil conditions, and cultivation practices; farmers must, therefore, consider all these factors. For example, a number of authors [15] suggest that oleic acid content can be significantly affected by irrigation, therefore, when safflower is cultivated under irrigation conditions there is no difference between cooler and warmer areas. Vice versa, the authors note that a reduction of 3-5\% in oleic acid content percentage is expected when safflower is grown in warmer locations under dry conditions. This same concept has been confirmed in other studies [49]. Literature shows different mean values of oil content percentage mainly depending on the cultivation area and cultivation practices of safflower. Oil content, in fact, was reported as 26-37\% in Greece [50], 24-40\% in China [51], 23-40\% in Iran [5], 26-36\% in Egypt [2], and 16-32\% in Turkey [52]. In our study, oil content percentages of the seeds were similar to those recorded in other studies carried out under dry conditions in a warm climate. Concerning oil yield, literature reports values ranging from 0.20 to $0.70 \mathrm{tha}^{-1}$ on average $[13,44,48,53]$. If we compare our findings with those reported in these studies, we find consistent oil yield values. Therefore, it is possible to say that, in Sicily, despite lower seed yields, safflower could be considered a valuable crop for agricultural and industrial purposes due to high oil content and seed yield, and could compete well with other oilseed crops, as a starting crop, in traditional cereal cropping systems in the Mediterranean area. Oleic, linoleic, palmitic and stearic acids are the main fatty acids in safflower oil, but oleic and linoleic acids significantly affect oil quality, more than the other fatty acids due to direct effects on human health, as stated in literature. Therefore, knowing the oleic and linoleic acid content in the seed oil is extremely important in order to characterise a safflower germplasm, both from an agronomic and an economic point of view. It has been demonstrated that safflower does not always exhibit the same fatty acid composition, varying mainly from year to year, with cultivation practices and genotype $[13,20,54]$. The quality of the oil is also affected by environmental factors, such as climate and soil. Changes in these factors can produce differences in the biochemical characteristics of the oil in plants of the same species grown in different environments. This concept has also been suggested by various authors $[55,56]$ for a number of medicinal species. It has been shown $[15,57]$ that air temperature and moisture can be considered the most important climatic factors affecting linoleic and oleic acid contents. In our study, the direct effects of air temperature and moisture on the fatty acid content of the 17 safflower accessions tested under dry conditions were not evaluated, but two main groups of accessions based on oleic and linoleic contents were recorded. Furthermore, on the basis of PCA findings, variations in seed yield and oleic and linoleic acid content highlighted the possibility of improving seed yield and oil quality through breeding or cultivation programmes using varying energy inputs, for example. As seed yield and fatty acid ratios are fundamental for the market value of safflower, it is reasonable to suppose that accessions with the highest seed yield and content of oleic and linoleic acids can be regarded as valuable genetic material for improvements in safflower oil quality in the Mediterranean region.

\section{Conclusions}

This study shows that safflower could be re-introduced in traditional cropping systems in arid and semi-arid areas of Sicily and is a viable alternative to other oilseed crops. All accessions in the study adapted well to Sicilian climate conditions and showed large variations in terms of seed and oil yields, and fatty acid composition. Positive and significant relationships between seed/oil yield and other tested traits were found. In this study, the evaluation of new safflower germplasm in Sicily led to the selection of two high oleic and high linoleic types. This diversity, based on the relative proportions of fatty acids in the seed oil, shows the large potential of safflower in agronomic and economic terms. It is clear that as yield components, oil quality and fatty acid composition are significantly affected by climate, genetic and cultivation factors, further studies are needed in order to understand the best cultivation requirements under Mediterranean climate conditions and to conserve this potentially 
valuable genetic resource. This appears fundamental for the future large-scale cultivation of this species in Southern Italy. This study confirms the interest of safflower for both food and non-food applications, opening up interesting prospects in arid conditions.

Supplementary Materials: The following are available online at http://www.mdpi.com/xxx/s1, Figure S1: a view of safflower germplasm accessions experimental field. Figure S2: safflower flowering stage. Figure S3: safflower senescence stage and capitula browning. Figure S4: safflower seeds.

Author Contributions: Conceptualization, L.L. and S.L.B.; methodology, L.L. and S.L.B.; software, M.L.; validation, L.L., S.L.B. and T.T.; formal analysis, M.L. and S.L.B.; investigation, L.L. and S.L.B.; resources, L.L., S.L.B. and R.M.; data curation, S.L.B., M.L., L.L. and R.M.; writing—original draft preparation, M.L.; writing-review and editing, S.L.B., M.L., L.L. and R.M.; visualization, T.T. and R.M.; supervision, C.L. and L.L.; project administration, L.L. and S.L.B.; funding acquisition, L.L. and S.L.B.

Funding: This research was funded by Italian Ministry of Education, University and Research (Grant No. CTN01_00063_49295).

Acknowledgments: The authors would like to thank the Italian Ministry of Education, University and Research for funding "BIT3G" project. A special thanks goes to Ignazio Cammalleri and Giuseppe Bonsangue for their technical assistance in the field activities and to Lucie Branwen Hornsby for her linguistic assistance.

Conflicts of Interest: The authors declare no conflict of interest. The funders had no role in the design of the study; in the collection, analyses, or interpretation of data; in the writing of the manuscript, or in the decision to publish the results.

\section{References}

1. Beyyavas, V.; Haliloglu, H.; Copur, O.; Yilmaz, A. Determination of seed yield and yield components of some safflower (Carthamus tinctorius L.) cultivars, lines and populations under the semi-arid conditions. Afr. J. Biotechnol. 2011, 10, 527-534. [CrossRef]

2. El-Lattief, E.A. Evaluation of 25 safflower genotypes for seed and oil yields under arid environment in upper Egypt. Asia J. Crop Sci. 2012, 1-8. [CrossRef]

3. Cho, M.H.; Paik, Y.S.; Hahn, T.R. Enzymatic conversion of pre-carthamin to carthamin by purified enzyme from the yellow petals of safflower. J. Agric. Food Chem. 2000, 48, 3917-3921. [CrossRef] [PubMed]

4. Corleto, A. Safflower project: On-farm introduction of safflower as an alternative oil crop in Southern Italy. In Proceedings of the Vth International Safflower Conference, Williston, ND, USA, 23-27 July 2001; Bergman, J.W., Múndel, H.H., Eds.; North Dakota State University: Fargo, ND, USA, 2001; pp. 179-184.

5. Omidi, A.H.; Khazaei, H.; Hongbo, S. Variation for some important agronomic traits in 100 spring safflower (Carthamus tinctorius L.) genotypes. Am.-Eur. J. Agric. Environ. Sci. 2009, 5, 791-795.

6. Fatahi, N.; Carapetian, J.; Heidari, R. Spectrophotometric measurement of valuable pigments from petals of safflower (Carthamus tinctorius L.) and their identification by TLC method. Res. J. Biol. Sci. 2008, 3, 761-763.

7. Danieli, P.P.; Primi, R.; Ronchi, B.; Ruggeri, R.; Rossini, F.; Del Puglia, S.; Cereti, C.F. The potential role of spineless safflower (Carthamus tinctorius L. var. inermis) as fodder crop in central Italy. Ital. J. Agron. 2011, 6, 19-22. [CrossRef]

8. Carvalho, I.S.; Miranda, I.; Pereira, H. Evaluation of oil composition of some crops suitable for human nutrition. Ind. Crop. Prod. 2006, 24, 75-78. [CrossRef]

9. Khan, M.A.; von Witzke-Ehbrecht, S.; Maass, B.L.; Becker, H.C. Relationships among different geographical groups, agro-morphology, fatty acid composition and RAPD marker diversity in Safflower (Carthamus tinctorius). Genet. Resour. Crop Evol. 2009, 56, 19-30. [CrossRef]

10. Rudolphi, S.; Becker, H.C.; Schierolt, A.; von Witzke-Ehbrecht, S. Improved estimation of oil, linoleic and oleic acid and seed hull fractions in safflower by NIRS. J. Am. Oil Chem. Soc. 2012, 89, 363-369. [CrossRef]

11. Ekin, Z. Resurgence of Safflower (Carthamus tinctorius L.) utilization: A global view. J. Agron. 2005, 4, 83-87. [CrossRef]

12. de Oliveira, C.V.K.; Santos, R.F.; Siqueira, J.A.C.; Bariccatti, R.A.; Lenz, N.B.G.; Cruz, G.S.; Tokura, L.K.; Klajn, F.F. Chemical characterization of oil and biodiesel from four safflower genotypes. Ind. Crop. Prod. 2018, 123, 192-196. [CrossRef]

13. Çamaş, N.; Çirak, C.; Esendal, E. Seed yield, oil content and fatty acid composition of safflower (Carthamus tinctorius L.) grown in northern Turkey conditions. J. Fac. Agric. OMU 2007, 22, 98-104. 
14. Coşge, B.; Gurbuz, B.; Kiralan, M. Oil content and fatty acid composition of some safflower (Carthamus tinctorius L.) varieties sown in spring and winter. Int. J. Nat. Eng. Sci. 2007, 1, 11-15.

15. Anjani, K.; Yadav, P. High yielding-high oleic non-genetically modified Indian safflower cultivars. Ind. Crop. Prod. 2017, 104, 7-12. [CrossRef]

16. Velasco, L.; Fernández-Martínez, J. Breeding for oil quality in Safflower. In Proceedings of the Vth International Safflower Conference, Williston, ND, USA, 23-27 July 2001; Bergman, J.W., Mûndel, H.H., Eds.; North Dakota State University: Fargo, ND, USA, 2001; pp. 133-137.

17. Hamdan, Y.A.S.; Perez-Vich, B.; Fernandez-Martinez, J.M.; Velasco, L. Inheritance of very high linoleic acid content and its relationship with nuclear male sterility in safflower. Plant Breed. 2008, 127, 507-509. [CrossRef]

18. Galavi, M.; Romroudi, M.; Tavassoli, A. Effect of micronutrientes foliar application on yield and seed oil content of safflower (Carthamus tinctorius). Afr. J. Agric. Res. 2012, 7, 482-486.

19. Knowles, P.F.; Hill, A.B. Inheritance of fatty acid content in the seed oil of a safflower introduction from Iran. Crop Sci. 1964, 4, 406-409. [CrossRef]

20. Gecgel, U.; Demirci, M.; Esendal, E.; Tasan, M. Fatty acid composition of the oil from developing seeds of different varieties of safflower (Carthamus tinctorius L.). J. Am. Oil Chem. Soc. 2007, 84, 47-54. [CrossRef]

21. Fernández-Martínez, J.; Rio, M.D.; Haro, A.D. Survey of safflower (Carthamus tinctorius L.) germplasm for variants in fatty acid composition and other seed characters. Euphytica 1993, 69, 115-122. [CrossRef]

22. Corleto, A.; Alba, E.; Polignano, G.B.; Vonghio, G. Safflower: A multipurpose species with unexploited potential and world adaptability. In Proceedings of the IVth International Safflower Conference, Bari, Italy, 2-7 June 1997; pp. 23-31.

23. Yeilaghi, H.; Arzani, A.; Ghaderian, M. Evaluating the contribution of ionic and agronomic components toward salinity tolerance in safflower. Agron. J. 2015, 107, 2205-2212. [CrossRef]

24. Izquierdo, N.; Aguirrezabal, L.; Andrade, F.; Pereyra, V. Night temperature affects fatty acid composition in sunflower oil depending on the hybrid and the phenological stage. Field Crop. Res. 2002, 7, 115-126. [CrossRef]

25. Yeilaghi, H.; Arzani, A.; Ghaderian, M.; Fotovat, R.; Feizi, M.; Pourdad, S.S. Effect of salinity on seed oil content and fatty acid composition of safflower (Carthamus tinctorius L.) genotypes. Food Chem. 2012, 130, 618-625. [CrossRef]

26. Amini, H.; Arzani, A.; Karami, M. Effect of water deficiency on seed quality and physiological traits of different safflower genotypes. Turk. J. Biol. 2014, 38, 271-282. [CrossRef]

27. Lazzeri, L.; D’Avino, L.; Mazzoncini, M.; Antichi, D.; Mosca, G.; Zanetti, F.; Del Gatto, A.; Pieri, S.; De Mastro, G.; Grassano, N.; et al. On farm agronomic and first environmnetal evaluation of oil crops for sustainable bioenergy chain. Ital. J. Agron. 2009, 4, 171-180. [CrossRef]

28. Stamigna, C.; Chiaretti, D.; Chiaretti, E.; Prosini, P.P. Oil and furfural recovery from Brassica carinata. Biomass Bioenergy 2012, 39, 478-483. [CrossRef]

29. Licata, M.; La Bella, S.; Lazzeri, L.; Matteo, R.; Leto, C.; Massaro, F.; Tuttolomondo, T. Agricultural feedstocks of two Brassica oilseed crops and energy cogeneration with pure vegetable oil for a sustainable short agro-energy chain in Sicily (Italy). Ind. Crop. Prod. 2018, 117, 140-148. [CrossRef]

30. Montemurro, F.; Diacono, M.; Scarcella, M.; D’Andrea, L.; Boari, F.; Santino, A.; Mastrorilli, M. Agronomic performance for biodiesel production potential of Brassica carinata A. Braun in Mediterranean marginal areas. Ital. J. Agron. 2016, 5, 57-64. [CrossRef]

31. Tavarini, S.; Angelini, L.G.; Casadei, N.; Spugnoli, P.; Lazzeri, L. Agronomical evaluation and chemical characterization of Linum usitatissimum L. as oilseed crop for bio-based products in two environments of Central and Northern Italy. Ital. J. Agron. 2016, 11, 122-132. [CrossRef]

32. Licata, M.; La Bella, S.; Leto, C.; Bonsangue, G.; Gennaro, M.C.; Tuttolomondo, T. Agronomic evaluation of Ethiopian mustard (Brassica carinata A. Braun) germplasm and physical-energy characterization of crop residues in a semi-arid area of Sicily (Italy). Chem. Eng. Trans. 2017, 58, 535-540. [CrossRef]

33. Spugnoli, P.; Dainelli, R.; D'Avino, L.; Mazzoncini, M.; Lazzeri, L. Sustainability of sunflower cultivation for biodiesel production in Tuscany within the EU Renewable Energy Directive. Biosyst. Eng. 2012, 112, 49-55. [CrossRef] 
34. Servizio Informativo Agrometeorologico Siciliano. Available online: www.sias.regione.sicilia.it (accessed on 21 September 2015).

35. Lancashire, P.D. A uniform decimal code for growth stages of crops and weeds. Ann. Appl. Biol. 1991, 119, 561-601. [CrossRef]

36. ISO 22630 2015. Oilseed Meals-Determination of Oil Content_Rapid Extraction Method; ISO: Geneva, Switzerland, 2015.

37. Mariotti, F.; Tomè, D.; Mirand, P.P. Converting nitrogen into protein-beyond 6.25 and Jones' factors. Crit. Rev. Food Sci. Nutr. 2008, 48, 177-184. [CrossRef]

38. Maehre, H.K.; Dalheim, L.; Edvinsen, G.K.; Elvevoll, E.O.; Jensen, I.J. Protein determination-Method Matters. Foods 2018, 7, 5. [CrossRef]

39. Conte, L.S.; Leoni, O.; Palmieri, S.; Capella, P.; Lercker, G. Half-seed analysis: Rapid chromatographic determination of the main fatty acids of sunflower seed. Plant Breed. 1989, 102, 158-165. [CrossRef]

40. ISO 12966-4 2015. Animal and Vegetable Fats and Oils-Gas Chromatography of Fatty Acid Methyl Esters-Part 4: Determination by Capillary Gas Chromatography; ISO: Geneva, Switzerland, 2015.

41. Alizadeh, H.; Jirair, C. Genetic variation in a safflower germplasm grown in rainfed cold drylands. J. Agron. 2006, 5, 50-52. [CrossRef]

42. Koutroubas, S.D.; Papakosta, D.K.; Doitsinis, A. Cultivar and seasonal effects on the contribution of pre-anthesis assimilates to safflower yield. Field Crop Res. 2004, 90, 263-274. [CrossRef]

43. Bagawan, I.; Ravikumar, R.L. Strong undesirable linkages between seed yield and oil components-A problem in safflower improvement. In Proceedings of the Vth International Safflower Conference, Williston, ND, USA, 23-27 July 2001; Bergman, J.W., Múndel, H.H., Eds.; North Dakota State University: Fargo, ND, USA, 2001; pp. 143-149.

44. Alizadeh, K. Evaluation of safflower germplasm by some agronomic characteristics and their relationships on grain yield production in the cold dry land of Iran. Int. J. Agric. Biol. 2005, 3, 389-391.

45. Cosentino, S.; Copani, V.; Camarata, M. Relations between meteorological parameters yield and seed oil content in safflower in Mediterranean environment. In Proceedings of the IVth International Safflower Conference, Bari, Italy, 2-7 June 1997; pp. 149-155.

46. Mohammadi, M.; Ghassemi-Golezani, K.; Chaichi, M.R.; Safikhani, S. Seed oil accumulation and yield of safflower affected by water supply and harvest time. Agron. J. 2018, 110, 1-8. [CrossRef]

47. Özel, A.; Demirbilek, T.; Gür, M.A.; Çopur, O. Effects of different sowing date and intrarow spacing on yield and some agronomic traits of safflower (Carthamus tinctorius L.) under Harran Plain's arid conditions. Turk. J. Agric. For. 2004, 28, 413-419.

48. Bassil, E.S.; Kaffka, S.R. Response of safflower (Carthamus tinctorius L.) to saline soils and irrigation: I. Consumptive water use. Agric. Water Manag. 2002, 54, 67-80. [CrossRef]

49. Ashrafi, E.; Razmjoo, K. Effect of irrigation regimes on oil content and composition of safflower (Carthamus tinctorius L.) cultivars. J. Am. Oil Chem. Soc. 2010, 87, 499-506. [CrossRef]

50. Koutroubas, S.D.; Papakosta, D.K. Adaptation, grain yield and oil content of safflower in Greece. In Proceedings of the VIth International Safflower Conference, Istanbul, Turkey, 6-10 June 2005; pp. 161-166.

51. Zhang, Z.; Chen, T. Studies on ecological adaptability of safflower germplasms in Xinjiang, China. In Proceedings of the VIth International Safflower Conference, Istanbul, Turkey, 6-10 June 2005; pp. 132-138.

52. Arslan, B.; Culpan, E. Identification of suitable safflower genotypes for the development of new cultivars with high seed yield, oil content and oil quality. Azarian J. Agric. 2018, 5, 133-141.

53. Gawand, P.B.; Tambe, S.I.; Reddy, B.N. Evaluation of productivity of safflower cultivars under moinsture and nutrient management in rainfed vertisols. In Proceedings of the VIth International Safflower Conference, Istanbul, Turkey, 6-10 June 2005; pp. 205-210.

54. Oz, M. Relationship between sowing time, variety, and quality in safflower. J. Chem. 2016, 1-8. [CrossRef]

55. Tuttolomondo, T.; Leto, C.; Leone, R.; Licata, M.; Virga, G.; Ruberto, G.; Napoli, E.M.; La Bella, S. Essential oil characteristics of wild Sicilian oregano populations in relation to environmental conditions. J. Essent. Oil Res. 2014, 26, 210-220. [CrossRef] 
56. Tuttolomondo, T.; Dugo, G.; Leto, C.; Cicero, N.; Tropea, A.; Virga, G.; Leone, R.; Licata, M.; La Bella, S. Agronomical and chemical characterisation of Thymbra capitata (L.) Cav. biotypes from Sicily, Italy. Nat. Prod. Res. 2015, 29, 1289-1299. [CrossRef]

57. Baydar, H.; Turgut, I. Variation of fatty acid composition according to some morphological and physiological properties and ecological regions in oilseed plants. Turk. J. Agric. For. 1999, 23, 81-86.

(C) 2019 by the authors. Licensee MDPI, Basel, Switzerland. This article is an open access article distributed under the terms and conditions of the Creative Commons Attribution (CC BY) license (http://creativecommons.org/licenses/by/4.0/). 